\title{
Screening for Sodium-Salt Tolerance at the Seedling Stage of Rice (Oryza sativa L.) Genotypes from Sudan and South Sudan
}

\author{
Seif Gasim ${ }^{1}$, Ishraka Abuanja ${ }^{1}$, Mohamedsalih Dafalla ${ }^{2}$ and Abdelwahab Abdalla ${ }^{1}$ \\ 1. Department of Agronomy, Faculty of Agriculture, University of Khartoum, Shambat 13314, Sudan \\ 2. Department of Soil Science, Faculty of Agriculture, University of Khartoum, Shambat 13314, Sudan
}

\begin{abstract}
Morpho-physiological and genetic studies of salinity are important in understanding the mechanism of plant adaptation to stressful environment. Eighteen rice genotypes collected from Sudan and South Sudan, which were never tested for salt tolerance, as well as two genotypes (FL478 as tolerant check and IR29 as sensitive check) from the International Rice Research Institute (IRRI), were subjected to salinity stress at seedling stage. Test was carried out in hydroponic system applying electrical conductivity (EC) 12 $\mathrm{dS} / \mathrm{m} \mathrm{NaCl}$ using randomized complete block design with three replicates. Most of the genotypes showed sensitivity to salt stress; one genotype PIPANFARY RED2 was moderately sensitive and three genotypes MASURY1, MASURY2 and FL478 were tolerant. Salinity significantly reduced leaf dry weight, shoot dry weight, root dry weigh and biomass production (biomass/plant) by $31 \%$, $42 \%, 60 \%$ and $47 \%$, respectively. Tolerant genotypes accumulated low amount $\left(2.52 \mathrm{~g} / 100 \mathrm{~g}\right.$ dry weight (dwt)) of $\mathrm{Na}^{+}$in the root, whereas highly sensitive genotypes accumulated high amount $(3.87 \mathrm{~g} / 100 \mathrm{~g} \mathrm{dwt})$ of $\mathrm{Na}^{+}$. Tolerant genotypes showed less reduction in $\mathrm{K}^{+}$concentration than the sensitive genotypes. Therefore, they maintained lowest $\mathrm{Na}^{+} / \mathrm{K}^{+}$ratio in the shoot $(1.47 \%)$ than in the root (3.69\%) compared to the intolerant genotypes ( $7.49 \%$ and $8.49 \%)$. The genotypes that showed tolerance to salinity stress can be used as a source of resistance/tolerance in a breeding program for rice improvement in uplands areas in semi-arid condition.
\end{abstract}

Key words: Rice, salt tolerance, seedling stage, plant tissue.

\section{Introduction}

Salinity is a major constraint restricting rice productivity across many rice production areas [1]. It is a worsening problem particularly in inland areas of arid and semi-arid due to the buildup of salinity as a consequence of excessive use of irrigation water with improper drainage coupled with the use of poor quality irrigation.

Rice susceptibility to salinity changes with the stage of development; germination, active tillering and maturation stages are less susceptible to salinity than to the seedling and early reproductive stages $[1,2]$. Recently, considerable progress was made in understanding the physiological bases of salt tolerance

Corresponding author: Seif Gasim, associate professor, research field: plant breeding. in rice and salt tolerant genotypes were developed [3, 4]. However, due to their local adaptation, landraces cultivars are being used as potential genetic resources of stress tolerance traits [5].

A large contributor to salinity stress is the build-up of the sodium ion $\left(\mathrm{Na}^{+}\right)$in the cytoplasm of leaf cells. High cytoplasmic $\mathrm{Na}^{+}$interferes with processes that require the binding of potassiumion $\left(\mathrm{K}^{+}\right)$, protein synthesis and the activation of key metabolic enzymes [6]. One key mechanism of salinity tolerance is the ability of a plant to control $\mathrm{Na}^{+}$transport at both the tissue and cell levels, either by secreting $\mathrm{Na}^{+}$into tissues, cells and organelles where it can do little damage, or by minimizing the amount of $\mathrm{Na}^{+}$entering the plant through its roots [6, 7]. In Sudan, most of the rice cultivated areas are of flood and salinity. However, no information is available on the 
mechanism of salinity tolerance of the locally grown cultivars. Therefore, the objective of the present study was to evaluate salinity tolerance of some Sudanese genotypes (never evaluated for their salt tolerance) during the early seedling stage and to identify the mechanism of tolerance with reference to $\mathrm{Na}^{+}$and $\mathrm{K}^{+}$ uptake.

\section{Materials and Methods}

2.1 Planting Material, Experimental Design and Evaluation of Salinity

Eighteen rice genotypes were studied: seven of them were collected from Aweil, South Sudan (NBGS1, NBGS2, NBGS3, NBGA, BG400-1, BG90-2, $B A N B A N$ ) and eleven from Kosti, Sudan (MASURY1, PIPANFARY RED1, JAING ARRI RED, SOMMBOY, COMARWA, PAINJLA, PIPANFARY, TAGMIZEDO, PIPANFARY RED2, BACTING ARRI, MASURY2). In addition, two genotypes were provided by the International Rice Research Institute (IRRI) namely IR29 and FL478 used for salinity check; IR29 as sensitive check and FL478 as tolerant check [8, 9]. The seeds were first incubated for $3 \mathrm{~d}$ in an oven at $50{ }^{\circ} \mathrm{C}$ to break seed dormancy, soaked in distilled water and then incubated and pre-germinated in the dark at $32{ }^{\circ} \mathrm{C}$ until the seeds sprouted (in about $48 \mathrm{~h}$ ). Five germinating seeds from each genotype were transferred to styrofoam floats in a plastic container of $8 \mathrm{~L}$ capacity filled with deionized water and the entire setup was transferred to the green house of the IRRI. A randomized complete block design was used to carry out the experiment; entries were replicated three times. Two sets of treatments were used: one normal and the other saline. Three days later, the deionized water was replaced by Yoshida nutrient solution [10] for $4 \mathrm{~d}$. Electrical conductivity (EC) of the solution was adjusted by the addition of $\mathrm{NaCl}$ into $6 \mathrm{dS} / \mathrm{m}$ after $3 \mathrm{~d}$ and $12 \mathrm{dS} / \mathrm{m}$ after $6 \mathrm{~d}$. The $\mathrm{pH}$ was checked and adjusted every day within the range of 5.0-5.4 and nutrient solution was changed every week to maintain nutrients in the solution. IRRI's Standard Evaluation
System (SES) for rice [11] was used for evaluation of salinity tolerance in score $(3=$ tolerant; $5=$ moderate tolerant; $7=$ susceptible; $9=$ sensitive). Salinity effect started to appear in some genotypes from the second scoring then most of them reached high scoring of 7-9 after $14 \mathrm{~d}$ from subjecting the plants to salinity.

\section{$2.2 \mathrm{Na}^{+}$and $\mathrm{K}^{+}$Determination}

The plant samples (shoots and roots, separately) were transferred into labeled coin envelopes and put in an oven for drying at $70{ }^{\circ} \mathrm{C}$ to a constant weight. Then their dry weights were determined and homogenized using scissor and beaker and sub-samples of $20.5 \mathrm{mg}$ each were introduced into labeled $50 \mathrm{~mL}$ Falcon tubes. Then $20 \mathrm{~mL} 0.1 \mathrm{M}$ of acetic acid was added to each tube using an automatic dispensing burette. Extreme care was taken to thoroughly wet the sample with the acid, and the samples were digested in an oven at $60{ }^{\circ} \mathrm{C}$ for overnight per a couple of $5 \mathrm{~d}$, then the bottles were shaken gently and filtered through a Whatman filter papers No.1 into new set of labeled 50 $\mathrm{mL}$ Falcon tubes, and finally $1 \mathrm{~mL}$ of the filtered sample was transferred to $14 \mathrm{~mL}$ Falcon tubes using pipette, and diluted to $10 \mathrm{~mL}$ using Nano pure water for $\mathrm{Na}^{+}$and $\mathrm{K}^{+}$determination on an atomic absorption spectrometer (AAS) (Perkin Elmer A Analyst 400). Then $\mathrm{Na}^{+}$and $\mathrm{K}^{+}$concentrations were determined in percentage as follows:

$$
\% \mathrm{Na}^{+} \text {or } \mathrm{K}^{+}=\frac{\text { ppm volume }\left(\frac{20}{1000}\right) \times 100}{\text { Sample dry weight }}
$$

where, ppm volume is the amount of $\mathrm{Na}^{+}$or $\mathrm{K}^{+}$from the AAS, 20/1000 is the amount of solvent used for extraction in liter and 10 is the diluted volume. Moreover, leaf dry weight, shoot dry weight, root dry weight and biomass/plant were recorded under saline and control conditions.

\subsection{Screening for $\mathrm{Na}^{+}$Tolerance in Plant Tissue and Leaf to Leaf Compartmentation}

Based on the results of the effect of the salinity in the studied genotypes, two tolerant genotypes 
(MASURY1 and MASURY2) and two sensitive genotypes (BG400-1 and SOMMBOY) were selected, screened and compared with FL478 (tolerant check) and IR29 (sensitive check) for shoot sodium, tissue $\mathrm{Na}^{+}$tolerance and leaf to leaf compartmentation. The experiment was laid out using different salinity treatments (EC0, EC6, EC12 and EC18 or 0, 60, 90 and $120 \mathrm{mM}$ ) with three replications in a randomized complete block design. Seed treatments, incubation, germination and salinity treatments were carried out following the procedure mentioned above (the trays designed for different salinity treatments were salinized after $14 \mathrm{~d}$ ). Depending on the toxicity symptoms, the individual leaves (the youngest fully expanded leaf) of the genotype encompassing the range of observable symptoms in the highest salinity treatment (EC18) which reached an average SES of 9 were harvested from all salinity treatments and the control according to a wide range of damage that appeared. Then the samples were oven dried, weighed and $\mathrm{Na}^{+}$concentrations were determined as above. For leaf to leaf compartmentation screening, the seedlings were left to grow under Yoshida nutrients solution for $21 \mathrm{~d}$ then salinized with $\mathrm{NaCl}(6 \mathrm{~g} \mathrm{NaCl} / \mathrm{L} ; 12 \mathrm{dS} / \mathrm{m})$. In the following day, the leaf three (L3) and leaf four (L4) from two plants of each genotype were harvested (4 $\mathrm{d}$ after salinization). The samples were oven dried and weighed and subsamples were taken for $\mathrm{Na}^{+}$ extraction, and $\mathrm{Na}^{+}$concentration was determined on an AAS as mentioned before.

\subsection{Statistical Analysis}

Analysis of variance was carried out on the collected data using software Statistical Tool for Agricultural Research [12]. Least significant difference $\left(\mathrm{LSD}_{0.05}\right)$ was used for mean separation.

\section{Results}

Statistical analysis (data not shown) revealed that the effect of genotype and salt concentration level (salinity) were highly significant $(p \leq 0.01)$ for all of the phenotypic parameters under study (leaf dry weight, shoot dry weight, root dry weight and biomass/plant) and physiological traits (shoot $\mathrm{Na}^{+}$, shoot $\mathrm{K}^{+}$, shoot $\mathrm{Na}^{+} / \mathrm{K}^{+}$ratio, root $\mathrm{Na}^{+}$, root $\mathrm{K}^{+}$and root $\mathrm{Na}^{+} / \mathrm{K}^{+}$ratio). The effects of genotype, salinity as well as the effect of genotype $X$ salt concentration interaction were significant for all traits, except for root $\mathrm{Na}^{+}$, which revealed non-significant differences. When salt stress of $12 \mathrm{dS} / \mathrm{m}$ was applied, all of Aweil genotypes (South Sudan) were susceptible to salinity (SES values of 7.0-8.5). For Kosti genotypes (Sudan), two genotypes (MASURY1 and MASURY2) showed tolerance to salinity (SES values of 3.0-4.5), one genotype (PIPANFARY RED2) was moderately tolerant (SES value of 5-6.7) and one genotype (SOMMBOY) was highly sensitive to salinity stress (SES value of 9); the rest of the genotypes were susceptible (SES of 7.0-8.5) as shown in Table 1. Salinity caused great reduction in phenotypic parameters (leaf dry weight, shoot dry weight, root dry weight and biomass production) in all genotypes, except for FL478 (tolerant check), which showed an increase in shoot dry weight by $12 \%$ and in biomass/plant by $8 \%$ under saline condition (Table 1 ). On average, salinity caused a considerable reduction in leaf dry weight, shoot dry weight, root dry weight and biomass production by $31 \%, 42 \%, 60 \%$ and $47 \%$, respectively, after $14 \mathrm{~d}$ from salinization with high variation among genotypes. The results also showed that roots dry weight was the most severely affected trait under saline condition.

Table 2 shows the variation in the percentage of $\mathrm{Na}^{+}$and $\mathrm{K}^{+}$in shoots and roots of the genotypes measured after $14 \mathrm{~d}$ from salinization. $\mathrm{Na}^{+}$ concentration of different plant tissues of all genotypes was increased under saline condition than under control condition. The percentage of $\mathrm{Na}^{+}$ concentration in the shoot ranged from $2.354 \%$ (MASURY2) to $4.874 \%$ (BANBAN) and ranged in the root from $1.899 \%$ (NBGS3) to $3.285 \%$ (TAGMIZEDO). However, tolerant genotypes accumulated less amount 

Genotypes from Sudan and South Sudan

Table 1 Variation in 20 rice genotypes in Standard Evaluation System (SES) score, leaf dry weight, shoot dry weight, root dry weight and biomass/plant after $14 \mathrm{~d}$ from salinization under saline and control conditions.

\begin{tabular}{|c|c|c|c|c|c|c|c|c|c|c|}
\hline & Saline & Control & Saline & Control & Saline & Control & Saline & Control & Saline & Control \\
\hline Genotype & $\begin{array}{l}\text { SES } \\
\text { score }\end{array}$ & $\begin{array}{l}\text { SES } \\
\text { score }\end{array}$ & $\begin{array}{l}\text { Leaf dry } \\
\text { weight } \\
\text { (mg) }\end{array}$ & $\begin{array}{l}\text { Leaf dry } \\
\text { weight } \\
\text { (mg) }\end{array}$ & $\begin{array}{l}\text { Shoot dry } \\
\text { weight } \\
\text { (mg) }\end{array}$ & $\begin{array}{l}\text { Shoot dry } \\
\text { weight } \\
\text { (mg) }\end{array}$ & $\begin{array}{l}\text { Root dry } \\
\text { weight } \\
\text { (mg) }\end{array}$ & $\begin{array}{l}\text { Root dry } \\
\text { weight } \\
\text { (mg) }\end{array}$ & $\begin{array}{l}\text { Biomass } \\
\text { /plant } \\
\text { (mg) }\end{array}$ & $\begin{array}{l}\text { Biomass } \\
\text { /plant } \\
\text { (mg) }\end{array}$ \\
\hline NBGS1 & 7.7 & 1.0 & 17.1 & 26.9 & 278.2 & 480.5 & 74.2 & 154.4 & 176.2 & 317.5 \\
\hline NBGS2 & 7.7 & 1.0 & 21.3 & 26.7 & 312.2 & 508.8 & 78.9 & 154.7 & 195.6 & 331.8 \\
\hline NBGS3 & 8.0 & 1.0 & 18.9 & 40.9 & 221.1 & 607.8 & 60.3 & 217.5 & 140.7 & 412.7 \\
\hline$N B G A$ & 7.0 & 1.0 & 22.0 & 37.7 & 300.9 & 560.0 & 78.3 & 229.8 & 189.6 & 394.9 \\
\hline BG400-1 & 8.3 & 1.0 & 10.5 & 15.8 & 200.6 & 401.1 & 55.8 & 147.6 & 128.2 & 274.4 \\
\hline BG90-2 & 7.0 & 1.0 & 22.0 & 31.0 & 336.6 & 738.3 & 75.7 & 242.5 & 206.1 & 490.4 \\
\hline$B A N B A N$ & 8.0 & 1.0 & 32.4 & 47.9 & 243.1 & 690.3 & 61.9 & 263.5 & 152.5 & 476.9 \\
\hline MASURY1 & 4.3 & 1.0 & 33.7 & 53.5 & 653.4 & 748.3 & 175.4 & 261.0 & 414.4 & 504.6 \\
\hline PIPANFARY RED1 & 8.3 & 1.0 & 25.6 & 29.0 & 335.4 & 746.7 & 101.7 & 348.9 & 218.6 & 547.8 \\
\hline JAING ARRI RED & 7.7 & 1.0 & 25.3 & 30.9 & 382.8 & 592.5 & 115.6 & 301.9 & 249.2 & 447.2 \\
\hline SOMMBOY & 9.0 & 1.0 & 33.1 & 57.1 & 368.2 & 862.9 & 96.7 & 480.8 & 232.5 & 671.8 \\
\hline COMARWA & 7.7 & 1.0 & 18.8 & 27.3 & 439.6 & 739.2 & 152.9 & 356.2 & 296.3 & 547.7 \\
\hline PAINJLA & 8.3 & 1.0 & 33.7 & 30.0 & 356.8 & 683.2 & 107.1 & 355.9 & 232.0 & 519.5 \\
\hline PIPANFARY & 8.3 & 1.0 & 17.9 & 34.0 & 296.4 & 465.3 & 93.2 & 267.1 & 194.8 & 366.2 \\
\hline TAGMIZEDO & 7.0 & 1.0 & 28.6 & 36.4 & 542.5 & 907.1 & 175.5 & 427.3 & 359.0 & 667.2 \\
\hline PIPANFARY RED2 & 5.3 & 1.0 & 28.5 & 37.9 & 476.8 & 629.6 & 158.4 & 269.8 & 317.6 & 449.7 \\
\hline BACTING ARRI & 7.0 & 1.0 & 20.9 & 30.5 & 397.8 & 668.3 & 108.1 & 371.4 & 253.0 & 519.9 \\
\hline MASURY2 & 3.7 & 1.0 & 26.1 & 41.3 & 511.0 & 655.0 & 159.3 & 249.8 & 335.1 & 452.4 \\
\hline FL478 (tolerant check) & 3.0 & 1.0 & 20.3 & 28.2 & 634.6 & 564.7 & 170.9 & 178.3 & 402.8 & 371.5 \\
\hline IR29 (sensitive check) & 9.0 & 1.0 & 13.4 & 16.6 & 204.9 & 428.0 & 66.8 & 152.5 & 135.8 & 290.2 \\
\hline Mean & 7.1 & 1.0 & 23.5 & 33.9 & 367.5 & 633.9 & 108.34 & 271.5 & 241.5 & 452.7 \\
\hline $\mathrm{LSD}_{0.05}$ & 1.3 & & 4.1 & & 79.2 & & 44.9 & & 58.7 & \\
\hline
\end{tabular}

of $\mathrm{Na}^{+}$in the shoot with a mean value of $2.52 \mathrm{~g} / 100 \mathrm{~g}$ dry weight (dwt), whereas susceptible genotypes accumulated higher amounts of $\mathrm{Na}^{+}$with a mean value of $3.87 \mathrm{~g} / 100 \mathrm{~g}$ dwt. On the other hand, the tolerant genotypes accumulated highest amount of $\mathrm{Na}^{+}$in the root $(2.51 \mathrm{~g} / 100 \mathrm{~g} \mathrm{dwt})$ than the highly sensitive genotypes (2.44 g/100 g dwt) (Table 2).

Nevertheless, sensitive genotypes absorbed more $\mathrm{Na}^{+}$and transferred high amount to the shoot, whereas the tolerant genotypes absorbed less $\mathrm{Na}^{+}$and retained most of it in their roots, therefore maintained higher shoot growth rate (Table 2). Due to the antagonistic properties of $\mathrm{Na}^{+}$and $\mathrm{K}^{+}$with increase in salt concentration, $\mathrm{K}^{+}$rate was decreased in all tissues, with variations among genotypes, except for the tolerant genotype MASURY1, which showed an increase in $\mathrm{K}^{+}$concentration in the shoot by 3\% (Table 2). The $\mathrm{K}^{+}$concentration in the shoot ranged from $0.545 \%$ (IR29 (sensitive check)) to $2.005 \%$ (MASURY1) and in the root it ranged from $0.181 \%$ (PIPANFARY RED1) to $0.806 \%$ (MASURY2).

The results in Table 3 show that salinity caused an increase in the ratio of $\mathrm{Na}^{+} / \mathrm{K}^{+}$in both shoot and root. The highest ratio of $\mathrm{Na}^{+} / \mathrm{K}^{+}$in the shoot was related to highly sensitive genotype (SOMMBOY, 7.499\%), whereas the lowest ratio was related to tolerant genotype (MASURY1, 1.306\%). On the other hand, the highest ratio of $\mathrm{Na}^{+} / \mathrm{K}^{+}$in root was related to highly sensitive genotype (JAING ARRI RED, 13.951\%), while the lowest ratio was related to moderately tolerant genotype (MASURY2, 3.211\%). The shoot and the root $\mathrm{Na}^{+} / \mathrm{K}^{+}$ratios increased under saline condition by $98 \%$ and $92 \%$ under control condition. Under saline condition, the tolerant genotypes exhibited lower amounts of $\mathrm{Na}^{+} / \mathrm{K}^{+}$ratio in the shoot $(1.468 \%)$ than in the root (3.690\%). But the highly 
Table 2 Variation in SES score and $\mathrm{Na}^{+}$and $\mathrm{K}^{+}$concentrationsin shoots and roots of 20 rice genotypes measured after $14 \mathrm{~d}$ from salinization under saline and control conditions.

\begin{tabular}{|c|c|c|c|c|c|c|c|c|}
\hline & Shoot & & Root & & Shoot & & Root & \\
\hline \multirow[t]{2}{*}{ Genotype/source } & Saline & Control & Saline & Control & Saline & Control & Saline & Control \\
\hline & $\mathrm{Na}^{+}$content & $\mathrm{Na}^{+}$content & $\mathrm{Na}^{+}$content & $\mathrm{Na}^{+}$content & $\mathrm{K}^{+}$content & $\mathrm{K}^{+}$content & $\mathrm{K}^{+}$content & $\mathrm{K}^{+}$content \\
\hline NBGS1 & 3.370 & 0.036 & 2.587 & 0.515 & 1.041 & 2.572 & 0.454 & 0.908 \\
\hline NBGS2 & 3.140 & 0.048 & 2.756 & 0.539 & 1.293 & 2.646 & 0.694 & 1.122 \\
\hline NBGS3 & 3.320 & 0.029 & 2.899 & 0.599 & 0.937 & 1.880 & 0.361 & 1.003 \\
\hline$N B G A$ & 3.499 & 0.053 & 2.762 & 0.681 & 1.264 & 2.022 & 0.540 & 0.968 \\
\hline BG400-1 & 3.125 & 0.087 & 2.441 & 0.356 & 0.862 & 1.555 & 0.389 & 0.855 \\
\hline BG90-2 & 3.982 & 0.058 & 2.420 & 0.645 & 0.863 & 2.663 & 0.385 & 0.988 \\
\hline$B A N B A N$ & 4.874 & 0.103 & 2.805 & 0.602 & 0.921 & 1.963 & 0.342 & 1.010 \\
\hline MASURY1 & 2.609 & 0.043 & 2.445 & 0.457 & 2.005 & 1.955 & 0.556 & 0.828 \\
\hline PIPANFARY RED1 & 4.315 & 0.141 & 2.268 & 0.536 & 0.771 & 2.112 & 0.181 & 0.857 \\
\hline JAING ARRI RED & 3.936 & 0.156 & 2.572 & 0.526 & 0.686 & 1.917 & 0.185 & 0.840 \\
\hline SOMMBOY & 3.761 & 0.155 & 2.820 & 0.622 & 0.571 & 2.045 & 0.229 & 0.918 \\
\hline COMARWA & 3.753 & 0.233 & 2.921 & 0.566 & 0.815 & 1.885 & 0.235 & 0.932 \\
\hline PAINJLA & 3.563 & 0.141 & 2.822 & 0.424 & 0.670 & 1.817 & 0.316 & 1.085 \\
\hline PIPANFARY & 4.091 & 0.262 & 2.752 & 0.687 & 0.607 & 1.982 & 0.299 & 0.942 \\
\hline TAGMIZEDO & 3.769 & 0.137 & 2.285 & 0.603 & 0.997 & 1.905 & 0.366 & 0.936 \\
\hline PIPANFARY RED2 & 2.429 & 0.067 & 2.715 & 0.555 & 1.418 & 1.895 & 0.677 & 0.999 \\
\hline BACTING ARRI & 4.010 & 0.102 & 2.021 & 0.588 & 0.859 & 1.881 & 0.344 & 0.903 \\
\hline MASURY2 & 2.354 & 0.104 & 2.508 & 0.470 & 1.453 & 1.919 & 0.806 & 1.144 \\
\hline FL478 (tolerant check) & 2.607 & 0.094 & 2.583 & 0.604 & 1.802 & 2.129 & 0.757 & 0.890 \\
\hline IR29 (sensitive check) & 3.544 & 0.082 & 2.344 & 0.537 & 0.545 & 1.869 & 0.303 & 1.162 \\
\hline Mean & 3.50 & 0.107 & 2.59 & 0.557 & 1.019 & 2.031 & 0.421 & 0.965 \\
\hline $\mathrm{LSD}_{0.05}$ & 0.70 & & 0.53 & & 0.25 & & 0.12 & \\
\hline
\end{tabular}

sensitive genotypes showed highest amount of $\mathrm{Na}^{+} / \mathrm{K}^{+}$ ratio in the shoot (7.049) and root (10.133\%). Under saline condition, tolerant genotypes maintained lowest $\mathrm{Na}^{+}$concentrations, highest $\mathrm{K}^{+}$concentrations and lowest $\mathrm{Na}^{+} / \mathrm{K}^{+}$ratios in the shoot than in the root; whereas sensitive genotypes attained highest $\mathrm{Na}^{+}$ concentrations, lowest $\mathrm{K}^{+}$concentrations, highest $\mathrm{Na}^{+} / \mathrm{K}^{+}$ratios in the shoot than in the root (Tables 2 and 3).

Screening for $\mathrm{Na}^{+}$in the selected accessions at different EC $(0,6,12$ and $18 \mathrm{dS} / \mathrm{m})$ indicated that the effect of genotype, salinity levels and genotype $\times$ salinity interaction were highly significant $(p \leq 0.01)$ in all plant leaves and in plant leaf tissue tolerance (data not shown). As a result, the mean values of genotypes and salinity levels were different from each other. In terms of tissue tolerance, tissue $\mathrm{Na}^{+}$ concentration increased with increasing the amount of
$\mathrm{NaCl}$ concentration; therefore, the highest level of $\mathrm{Na}^{+}$ concentration was reached with the level of EC18 (Table 4). The highest level of $\mathrm{Na}^{+}$concentration was shown by MASURY2 (4.178 g/100 g dwt), and the lowest level was obtained for the genotype MASURY1 ( $2.183 \mathrm{~g} / 100 \mathrm{~g} \mathrm{dwt})$. Compared to the tolerant check (FL478), MASURY2 exhibited the highest $\mathrm{Na}^{+}$ concentration $(3.446 \mathrm{~g} / 100 \mathrm{~g} \quad \mathrm{dwt})$, so the concentration of $\mathrm{Na}^{+}$in the tissue of MASURY2 was higher than that in the tolerant check. Moreover, the results showed that sensitive genotypes to salinity accumulated high $\mathrm{Na}^{+}$concentration but scored low SES, whereas tolerant genotypes accumulated low $\mathrm{Na}^{+}$and scored high SES (Fig. 1).

For leaf to leaf compartmentation, leaf three and leaf four, the amount of $\mathrm{Na}^{+}$content increased from day to day and reached the highest level in day four (four days after salinization (DAS)). The highest amount 
Table 3 Variation in $\mathrm{Na}^{+} / \mathrm{K}^{+}$ratio in shoots and roots of 20 rice genotypes measured after $14 \mathrm{~d}$ from salinization.

\begin{tabular}{|c|c|c|c|c|}
\hline \multirow{3}{*}{ Genotype } & \multicolumn{2}{|l|}{ Shoot } & \multicolumn{2}{|l|}{ Root } \\
\hline & Saline & Control & Saline & Control \\
\hline & $\mathrm{Na}^{+} / \mathrm{K}^{+}$ratio & $\mathrm{Na}^{+} / \mathrm{K}^{+}$ratio & $\mathrm{Na}^{+} / \mathrm{K}^{+}$ratio & $\mathrm{Na}^{+} / \mathrm{K}^{+}$ratio \\
\hline NBGS1 & 3.547 & 0.015 & 6.207 & 0.560 \\
\hline NBGS2 & 2.722 & 0.020 & 4.601 & 0.486 \\
\hline NBGS3 & 4.278 & 0.015 & 7.593 & 0.596 \\
\hline$N B G A$ & 2.930 & 0.025 & 5.611 & 0.698 \\
\hline BG400-1 & 4.926 & 0.060 & 9.035 & 0.416 \\
\hline BG90-2 & 4.692 & 0.023 & 6.798 & 0.657 \\
\hline BANBAN & 5.523 & 0.057 & 8.236 & 0.608 \\
\hline MASURY1 & 1.306 & 0.023 & 4.398 & 0.554 \\
\hline PIPANFARY RED1 & 5.797 & 0.068 & 12.298 & 0.627 \\
\hline JAING ARRI RED & 6.489 & 0.087 & 13.951 & 0.627 \\
\hline SOMMBOY & 7.499 & 0.077 & 12.368 & 0.683 \\
\hline COMARWA & 6.298 & 0.124 & 7.823 & 0.608 \\
\hline PAINJLA & 5.478 & 0.077 & 9.405 & 0.427 \\
\hline PIPANFARY & 6.790 & 0.137 & 9.496 & 0.731 \\
\hline TAGMIZEDO & 3.835 & 0.072 & 9.365 & 0.660 \\
\hline PIPANFARY RED2 & 1.981 & 0.035 & 4.213 & 0.559 \\
\hline BACTING ARRI & 4.899 & 0.055 & 9.788 & 0.662 \\
\hline MASURY2 & 1.652 & 0.053 & 3.211 & 0.414 \\
\hline FL478 (tolerant check) & 1.447 & 0.043 & 3.461 & 0.676 \\
\hline IR29 (sensitive check) & 6.600 & 0.045 & 7.898 & 0.463 \\
\hline Mean & 4.434 & 0.056 & 7.788 & 0.586 \\
\hline $\mathrm{LSD}_{0.05}$ & 1.03 & & 1.68 & \\
\hline
\end{tabular}

Table 4 Tissue sodium concentrations of six rice genotypes subjected to four different levels of salinity in hydroponic solution.

\begin{tabular}{lllll}
\hline \multirow{2}{*}{ Accessions } & \multicolumn{3}{c}{ Tissue sodium concentrations } \\
\cline { 2 - 5 } & $\mathrm{EC} 0$ & $\mathrm{EC} 6$ & $\mathrm{EC} 12$ & $\mathrm{EC} 18$ \\
\hline MASURY1 & 0.016 & 0.100 & 0.125 & 2.183 \\
MASURY2 & 0.007 & 0.056 & 0.929 & 4.178 \\
BG400-1 & 0.007 & 0.039 & 0.818 & 2.954 \\
SOMMBOY & 0.028 & 0.330 & 1.615 & 3.714 \\
FL478 (tolerant check) & 0.026 & 0.062 & 0.558 & 3.970 \\
IR29 (sensitive check) & 0.028 & 0.144 & 1.199 & 3.446 \\
Mean & 0.112 & 0.180 & 0.870 & 3.41 \\
LSD $_{0.05}$ & 0.003 & 0.012 & 0.002 & 0.001 \\
\hline
\end{tabular}

(625.1 mg/100 g dwt) of $\mathrm{Na}^{+}$content was scored by the genotype SOMMBOY and the lowest amount (30.7 $\mathrm{mg} / 100 \mathrm{~g} \mathrm{dwt}$ ) was obtained for BG400-1 (Table 5). On the other hand, sodium concentration in leaf three was higher than in leaf four for all rice accessions. The result also showed a negative correlation between leaf to leaf $\mathrm{Na}^{+}$concentration and SES score; thus, the genotypes with the highest leaf to leaf $\mathrm{Na}^{+}$concentration gave the lowest SES score (Fig. 2). Similarly, as shown in Fig. 3, the genotypes with the lowest SES score under salinity condition exhibited the highest tissue tolerance score, higher leaf to leaf compartmentation score and lower shoot sodium concentration, and the reverse is true for genotypes with lowest SES score. 


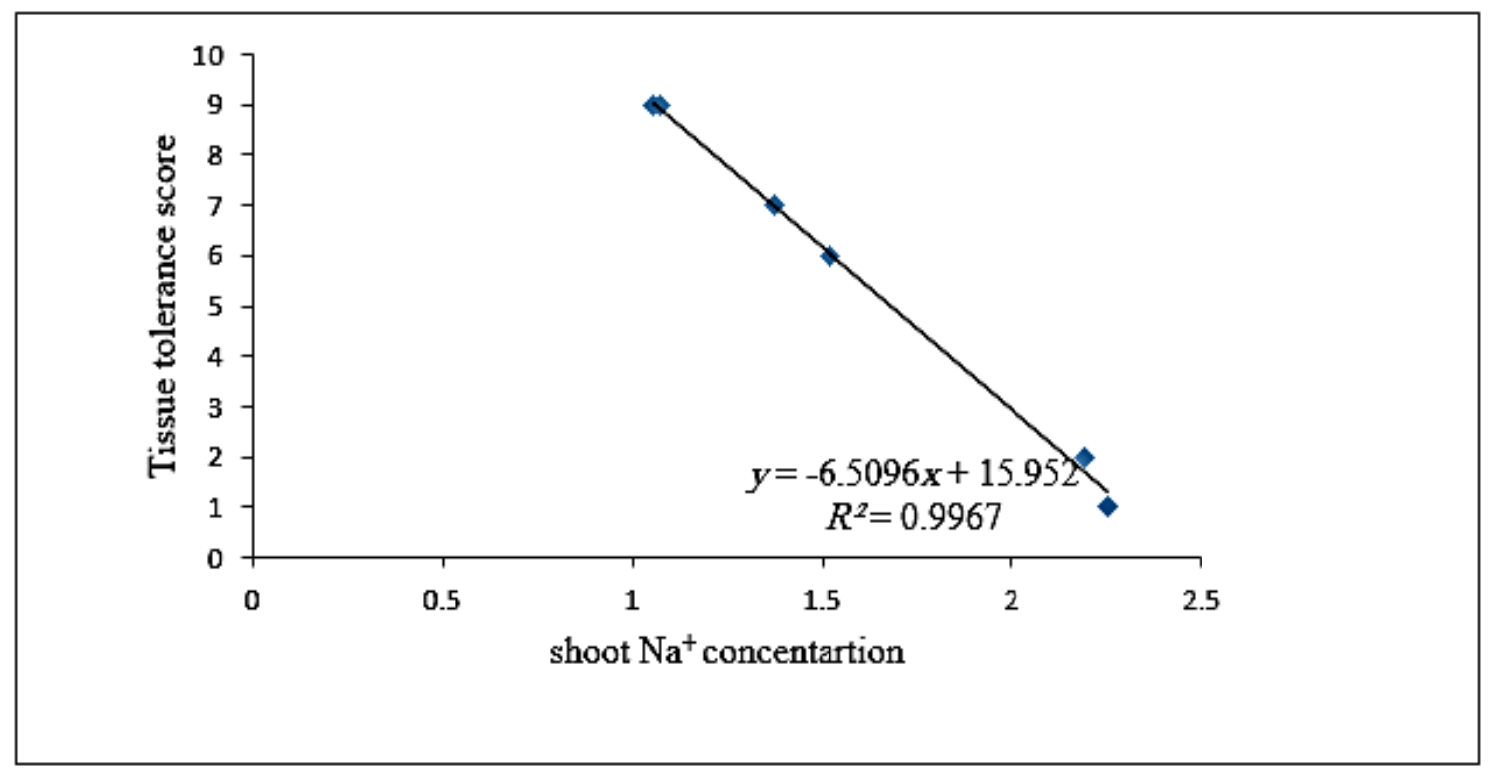

Fig. 1 Correlation between tissue tolerance score and shoot $\mathrm{Na}^{+}$concentration in six rice genotypes.

Table 5 Variation in sodium concentration in leaf three (L3) and leaf four (L4) of six rice accessions measured in four successive days after salinization (DAS).

\begin{tabular}{lllllllll}
\hline \multirow{2}{*}{ Accessions } & \multicolumn{3}{c}{ Sodium concentration in L3 } & \multicolumn{3}{c}{ Sodium concentration in L4 } \\
\cline { 2 - 8 } & 1 DAS & 2 DAS & 3 DAS & 4 DAS & 1 DAS & 2 DAS & 3 DAS & 4 DAS \\
\hline MASURY1 & 30.7 & 84.0 & 183.5 & 318.2 & 1.0 & 1.0 & 9.3 & 86.9 \\
MASURY2 & 12.0 & 200.6 & 245.7 & 367.9 & 1.3 & 1.4 & 6.0 & 164.1 \\
BG400-1 & 60.1 & 65.5 & 113.2 & 278.1 & 1.0 & 13.8 & 22.6 & 30.7 \\
SOMMBOY & 89.8 & 459.4 & 610.1 & 993.8 & 5.0 & 455.1 & 485.1 & 625.1 \\
FL478 (tolerant check) & 75.7 & 115.7 & 139.9 & 251.6 & 1.0 & 1.0 & 4.0 & 40.2 \\
IR29 (sensitive check) & 38.1 & 229.7 & 294.3 & 350.9 & 41.6 & 99.2 & 147.4 & 193.4 \\
\hline Mean & 51.07 & 192.48 & 264.45 & 426.75 & 8.48 & 110.37 & 112.40 & 190.07 \\
LSD $_{0.05}$ & 10.83 & 30.2 & 33.73 & 46.83 & 3.09 & 33.58 & 34.53 & 21.36 \\
\hline
\end{tabular}

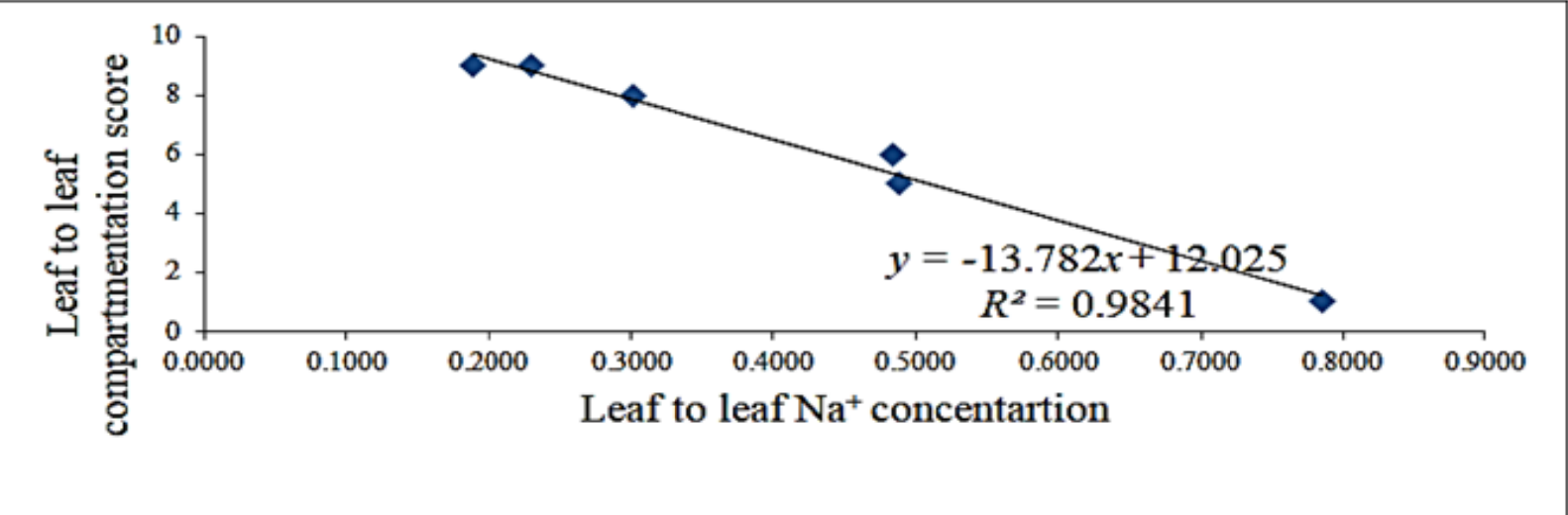

Fig. 2 Correlation between leaf to leaf $\mathrm{Na}^{+}$concentration and leaf to leaf compartmentation in six rice genotypes. 


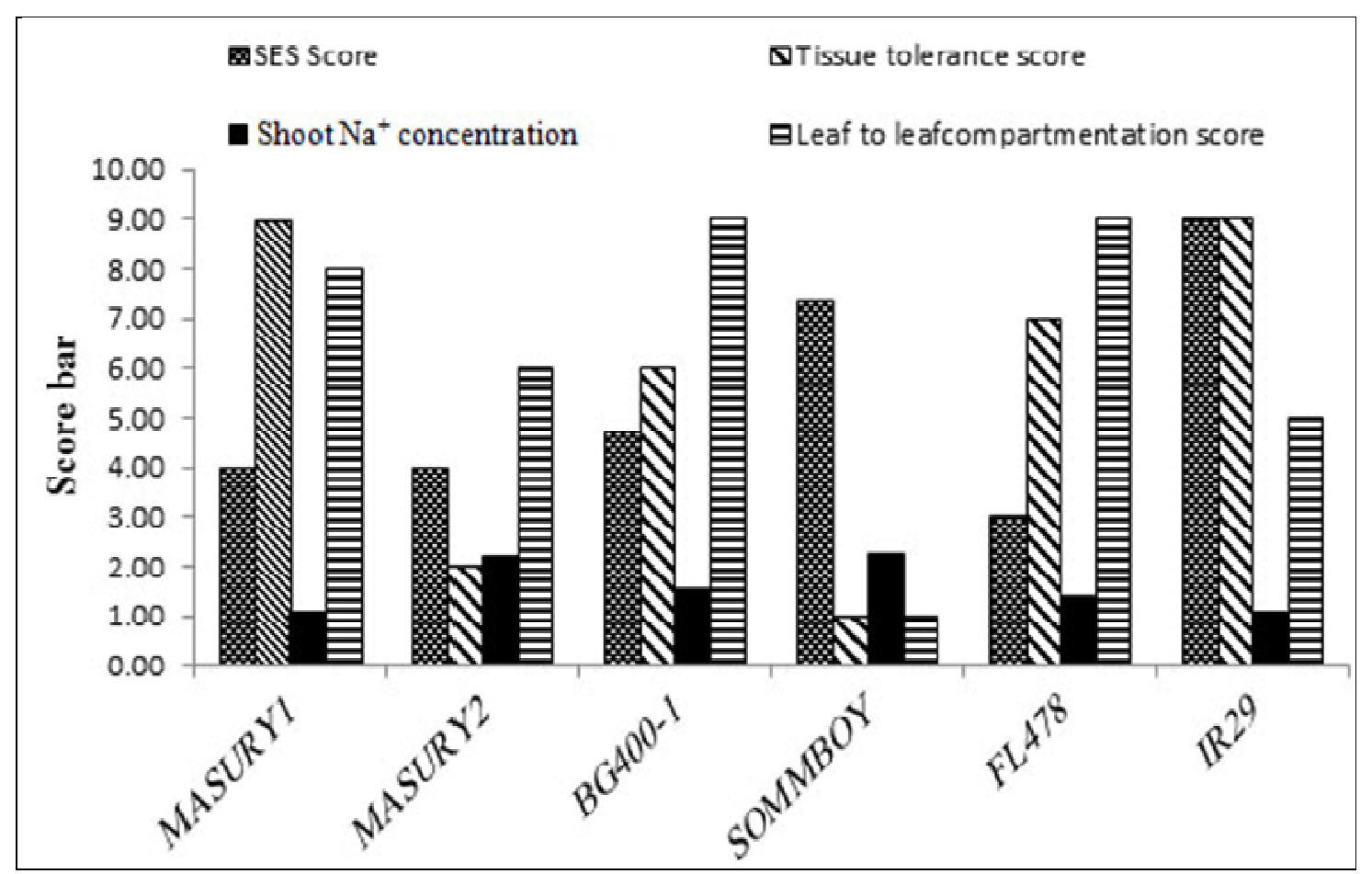

Fig. 3 SES score, tissue tolerance score, shoot $\mathrm{Na}^{+}$concentration and leaf to leaf compartmentation score of six rice genotypes.

\section{Discussion}

Salt tolerance in rice is complex, and involves several physiological and adaptive mechanisms [13, 14]. The physiological bases of salt tolerance during early seedling stage are fairly well understood; key traits include high seedling vigor with a consequent dilution of salt concentration in sensitive tissues, selective ion uptake at the root level, compartmentation of harmful ions in structural and old tissues in old leaves and roots, and high tissue tolerance through compartmentation of salts in the apoplast.

Genetic variation in salt tolerance has been frequently documented in rice as well as in other crop species [9]. However, sodium is the major cation that accumulates in plant tissues and organs when salinity increases. With significant effect of salt concentration and genotype interaction, different genotypes show different responses to salt concentration [15]. The non-significant effect of $\mathrm{Na}^{+}$concentration on root dry weight of the genotypes indicated that the difference between genotypes was not attributed to sodium accumulation in the roots, because most of the salt concentration was accumulated in the shoots rather than in the roots. When the rice genotypes were exposed to salt stress of $12 \mathrm{dS} / \mathrm{m}, 15$ genotypes from Sudan were sensitive, one (PIPANFARY RED2) was moderate and two (MASURY1and MASURY2) were tolerant to salinity, suggesting that evaluation at such level of salt concentration could be sufficient to detect accessions with reasonably high levels of tolerance of salt stress [8]. Also, this is an indication that there may be a gene governing the tolerance of these genotypes to salt stress, which is absent in the rest of the genotypes. This gene would be useful in environments with mild or moderate salt stress early in the season.

In the present study, tolerant genotypes showed less reduction percentage in phenotypic parameters, and intolerant genotypes exhibited high reduction percentage. The severe reduction in phenotypic parameters as a result of salinity stress indicates seedling stage is more sensitive to salinity stress [16, 17]. The increase in shoot dry weight and 
biomass/plant shown by FL478 was mostly due to their tolerance to salinity as reported by Moradi et al. [8]. Moreover, the severe effect of salinity on root dry weight could be attributed to the accumulation of most of the salts in the roots than in the shoots $[18,19]$. The significant variation among the genotypes due to salt stress indicates that increase in $\mathrm{Na}^{+}$concentration reduces $\mathrm{K}^{+}$concentration either in the shoots or in the roots. Under condition of high salt concentration, $\mathrm{Na}^{+}$ concentration was higher in the shoot than in the root, which led to reduction of $\mathrm{K}^{+}$concentration in the shoot and increase of $\mathrm{Na}^{+} / \mathrm{K}^{+}$ratio and this is one of the tolerance mechanisms in grasses, which limits the transport of $\mathrm{Na}^{+}$into photosynthetic cells and the growing of meristem active tissue [5]. Therefore, tolerant genotypes accumulated less amount of $\mathrm{Na}^{+}$in the shoot, high amount of $\mathrm{K}^{+}$and less ratio of $\mathrm{Na}^{+} / \mathrm{K}^{+}$, hence retained most of $\mathrm{Na}^{+}$content to the root, thus they maintained higher shoot growth rate. These findings agree with those of Peng and Ismail [14]. Moreover, the high concentration of $\mathrm{Na}^{+}$in the plant treated with $\mathrm{NaCl}$ suggests that the culture of the $\mathrm{NaCl}$ solution imposed ionic stress in the plant, in addition to the osmotic stress. This is further evidenced by the antagonistic effect of higher levels of $\mathrm{Na}^{+}$on $\mathrm{K}^{+}$ uptake, which has been shown to occur in previous studies with high concentrations of $\mathrm{Na}^{+}$in nutrient or soil solution [20].

The selected genotypes showed uniform green color under control condition. Tolerant (MASURY1 and MASURY2) and moderately tolerant (BG400-1) genotypes to salinity stress under salinized condition indicating their ability to tolerate $\mathrm{Na}^{+}$concentration as they showed less growth reduction in the studded parameters than intolerant (SOMMBOY) genotype, which agrees with the report of Castillo et al. [21]. When genotypes were exposed to different $\mathrm{EC}(0,6$, 12 and $18 \mathrm{dS} / \mathrm{m})$, the highest $\mathrm{Na}^{+}$concentration was reached at the level of EC18. The highest of level of $\mathrm{Na}^{+}$concentration exhibited by the MASURY2 (tolerant genotype) indicates that this genotype has a mechanism of compartmentation of salts in the apoplast to avoid buildup of toxic concentrations in the cytoplasm. This tolerance could probably be achieved through a set of active processes involving a gene family of ion transporters such as $\mathrm{Na}^{+} / \mathrm{H}^{+}$ antiporters that sequester salt in vacuoles [22] or move it out of the cell cytoplasm and recirculate it back to roots [23]. The highly significant variations between the genotypes for salt accumulation in leaf three (old leaf) than in leaf four (new leaf) suggesting the accumulation of salts in older leaves than in the newly growing leaves. The highest and lowest levels of $\mathrm{Na}^{+}$ concentrations in leaf three and leaf four achieved by the sensitive genotype (SOMMBOY) and the moderately tolerant genotype (BG400-1) in day four indicate that this moderately tolerant genotype has a mechanism of tissue tolerance by accumulation of $\mathrm{Na}^{+}$ in the vacuoles of the cell of the old leaves [6]. However, the lower SES score for the tolerant genotypes and the higher tissue tolerance score, higher leaf to leaf compartmentation score and lower shoot sodium concentration than for the intolerant genotypes indicate that genotypes with higher tissue tolerance maintain their cellular ultrastructure and have higher net photosynthesis at higher amounts of tissue salt concentration [3].

\section{Conclusions}

It could be concluded that salt stress severely affect the physiological traits, causing highly significant variability among the genotypes and the interaction between them. Tolerant genotypes accumulated lower amounts of sodium in the shoot and less reduction in $\mathrm{K}^{+}$concentration than the sensitive genotypes. Therefore, genotypes that showed tolerance to sodium salt stress could be used in breeding programs for tolerance of rice plants to salt stress in Sudan. Much work is needed to study the effect of salinity and sodicity on electrolyte concentration on growth parameters in rice plants in Sudan. In addition, understanding the molecular genetics and physiology 
of the traits affected by salt stress will form the basis for further improvements in salt tolerance of crop species.

\section{Acknowledgments}

Thanks are due to the ministry of Higher Education and Scientific Research for providing the fund to carry out the research work and to IRRI technicians for the technical assistance. Thanks are also extended to the Agricultural Research Corporation, Kosti, Sudan and Ministry of Agriculture, Bar Elgabal state, South Sudan for their help in providing the germplasm.

\section{References}

[1] Ali, M. N., Yeasmin, L., Gantait, S., Goswami, R., and Chakrabort, S. 2014. "Screening of Rice Landraces for Salinity Tolerance at Seedling Stage through Morphological and Molecular Markers." Physiol. Mol. Biol. Plants 20: 411-23.

[2] Hu, S., Tao, H., Qian, Q., and Guo, L. 2012. "Genetics and Molecular Breeding for Salt-Tolerance in Rice." Rice Genom. Genet. 3: 38-9.

[3] Ismail, A. M., Heuer, S., Thomson, M. J., and Wissuwa, M. 2007. "Genetic and Genomic Approaches to Develop Rice Germplasm for Problem Soils.” Plant Molecular Biology 65: 547-70.

[4] Thomson, M. J., de Ocampo, M., Egdane, J., Rahman, M. A., Sajise, A. G., Adorada, D. L., Tumimbang-Raiz, E., Blumwald, E., Seraj, Z. I., Singh, R. K., Gregorio, G. B., and Ismail, A. M. 2010. "Characterizing the Saltol Quantitative Trait Locus for Salinity Tolerance in Rice." Rice 3 (2-3): 148-60.

[5] Platten, J. D., Egdane, J. A., and Ismail, A. M. 2013. "Salinity Tolerance, $\mathrm{Na}^{+}$Exclusion and Allele Mining of HKT1;5 in Orayza sativa and O. glaberrima: Many Sources, Many Genes, One Mechanism.” BMC Plant Bio. 13: 32 .

[6] Munns, R., and Tester, M. 2008. "Mechanisms of Salinity Tolerance.” Annual Review of Plant Biology 59: 651-81.

[7] Apse, M. P., and Blumwald, E. 2007. "Na ${ }^{+}$Transport in Plants." FEBS Letters 581: 2247-54.

[8] Moradi, F., Ismail, A. M., Gregorio, G. B., and Egdane, J. A. 2003. "Salinity Tolerance of Rice during Reproductive Development and Association with Tolerance at the
Seedling Stage." Indian Journal of Plant Physiology 8: 276-8.

[9] Zhang, Z. H., Liu, Q., Song, H. X., Rong, X. M., and Ismail, A. M. 2012. "Responses of Different Rice (Oryza sativa L.) Genotypes to Salt Stress and Relation to Carbohydrate Metabolism and Chlorophyll Content." African Journal of Agricultural Research 7 (1): 19-27.

[10] Yoshida, S., Forno, D. A., Cock, I. H., and Gomez, K. A. 1976. Laboratory Manual for Physiological Studies of Rice. International Rice Research Institute (IRRI), Manila, Philippines.

[11] Gregorio, G. B., Senadhira, D., and Mendoza, R. D. 1997. Screening Rice for Salinity Tolerance. International Rice Research Institute (IRRI), Manila, Philippines.

[12] R-STAR. 2013. Statistical Tools for Agricultural Research, Version 1.1. International Rice Research Institute (IRRI), Los Baños, Philippines.

[13] Mishra, B., Singh, R. K., and Jetly, V. 1998. "Inheritance Pattern of Salinity Tolerance in Rice." Journal of Genetics and Breeding 52 (4): 325-31.

[14] Peng, S., and Ismail, A. M. 2004. "Physiological Basis of Yield and Environmental Adaptation in Rice." In: Physiology and Biotechnology Integration for Plant Breeding, edited by Nguyen, H. T., and Blum, A. New York, N.Y. (USA): Marcel Dekker Inc., 83-140.

[15] El-Hendawy, S. E., Hu, Y., and Schmidhalter, U. 2005. "Growth, Ion Content, Gas Exchange and Water Relations of Wheat Genotypes Differing in Salt Tolerances." Australian Journal of Agricultural Research 56: $123-34$

[16] Babu, V. R. 1985. "Seed Germination, Water Uptake and Seed Reserve Utilization of Rice (Oryza sativa cv. Jaya) under Growth Regulator and Salinity Stressed Conditions." Seed Research 11: 129-35.

[17] Fageria, N. K. 1985. "Salt Tolerance of Rice Cultivars." Plant Soil 88: 237-43.

[18] Suplick-Ploense, M. R., Qian, Y. L., and Read, L. C. 2002. "Salinity Tolerance of Texas Bluegrass, Kentucky Bluegrass and Their Hybrids." Crop Science 42: 2025-30.

[19] Bhowmik, S. K., Titov, S., Islam, M. M., Siddika, A., Sultana, S., and Haque, Md. S. 2009. "Phenotypic and Genotypic Screening of Rice Genotypes at Seedling Stage for Salt Tolerance." Global Journal of Biotechnology and Biochemistry 1 (2): 126-31.

[20] Nakhoda, B., Leung, H., Mendioro, M. S., 
Genotypes from Sudan and South Sudan

Mohammadi-nejad, G., and Ismail, A. M. 2012. "Isolation, Characterization, and Field Evaluation of Rice (Oryza sativa L., Var. IR64) Mutants with Altered Responses to Salt Stress." Field Crop Research 127: 191-202.

[21] Castillo, E. G., Toung, T. P., Ismail, A. M., and Inubushi, K. 2007. "Response to Salinity in Rice: Comparative Effect of Osmotic and Ionic Stresses." Plant Production
Science 10 (2): 159-70.

[22] Blumwald, E., Aharon, G. S., and Apse, M. P. 2000. "Sodium Transport in Plant Cells." Biochemistry and Biophysics Acta 1465: 140-51.

[23] Berthomieu, P., Conéjéro, G., and Nublat, A. 2003. "Functional Analysis of AtHKT1 in Arabidopsis Shows That $\mathrm{Na}^{+}$Recirculation by the Phloem is Crucial for Salt Tolerance.” The EMBO Journal 22: 2004-14. 